\title{
Research on Subjective Wellbeing and Depression of the Elderly in Social Pension Institutions in Calcutta
}

\author{
Hana Riani
}

\begin{abstract}
The present study aimed to explore the trends of depression among the elderly persons in an area of Kolkata. Accordingly, data had collected from purposively selected sample of 100 elderly (50 from Family/Home \& 50 from Old age Home, male \& female persons taken equally from Family \& Oldage Home). The data has been collected through specially designed general information Schedule and 'Geriatric Depression Inventory' (by J.A. Yesavith, 1982), responses of respondents were gathered to analyze the trends of Depression. Both qualitative and quantitative techniques were used for treatment of data. Interpreted results highlighted that trend of depression is higher in Old age Homes than that of Family/Home environment. Besides, women respondents are prone to depression in family and Old age Home both.
\end{abstract}

Keywords: Depression, Elderly persons, Family, Old age Home

\section{Introduction/ Background of the Study}

Though we are all living longer, people living with old age are in increasing trends. In each country, people are growing towards old age has a huge impact in population. By 2050 one in five people worldwide will be over 60 (American Association of Retired Persons-Articles / 2002-12). Asian nations have a larger proportion of elderly citizens dwelling in family as well as in old age home. Geriatric depression in increasing trends observed in old age population in Asian nations as well as all over the world. It has been revealed that notable percentages of geriatric population have been dwelling in old age Homes.

The present study will be an attempt to study whether elderly persons living in family and old age homes have any difference in their trends of depression.

Objectives:

1) To assess the difference between trends of depression among the elderly persons living in family and old age home.

2) To study the difference between trends of depression among the male and female old age population.

Hypotheses:

H-I There will be a significant difference among elderly persons living in family and old age home in relation to 'Depression'.

H-II There will be a significant difference between Male \& Female elderly persons living in family and old age home in relation to 'Depression'.

Tools / Measures used:

1) A general information schedule incorporating relevant variables had been administered by the investigator. ii) 'Geriatric Depression Inventory' (by J. A. Yesavith, 1982) has been used.
2) Source and Technique:

Respondents are 100 elderly persons divided into two groups (50 respondents, out of them 25 are female \& other 25 are male respondents in the both group) living in family and old age homes respectively to measure the depression level. Data has been collected individually following the sample selection criterion from different families and old age homes in an around Kolkata.

\section{3) Statistical Treatment:}

The collected data scored tabulated and treated with Mean, SD, $t$ Test and Co relation for verification of proposed hypothesis.

Table 1

Showing Mean scores about GDI among the Respondents:

\begin{tabular}{|c|c|c|}
\hline $\begin{array}{c}\text { Total } \\
(\mathrm{N}=100)\end{array}$ & $\begin{array}{c}\text { Mean of respondents of } \\
\text { Family/ Home }(\%)\end{array}$ & $\begin{array}{c}\text { Mean of respondents of } \\
\text { Old age Home }(\%)\end{array}$ \\
\hline $\begin{array}{c}\text { Geriatric } \\
\text { Depression }\end{array}$ & 6.53 & 12.7 \\
\hline
\end{tabular}

The above table shows that level of depression seems high among the respondents of old age home. Old age home respondents are very prone to depression. Level of depression shows low among the respondents of family. Data was collected from 100 individuals aged between 6075 years equally from Family and Old age home.

Table 2

Showing Mean, SD \& $\mathbf{t}$ Scores about Geriatric Depression Inventory among the Respondents (elderly persons) of Family and Old age Home:

\begin{tabular}{|c|c|c|c|c|c|}
\hline $\mathrm{N}=100$ & \multicolumn{2}{|c|}{$\begin{array}{c}\text { Total Respondents } \\
\text { of Family (N=50) }\end{array}$} & \multicolumn{2}{|c|}{$\begin{array}{c}\text { Total Respondents } \\
\text { of Old age Home } \\
(\mathrm{N}=50)\end{array}$} & \\
\hline & Mean & SD & Mean & SD & t-Test \\
\hline $\begin{array}{c}\text { GDS (Geriatric } \\
\text { Depression Scale) }\end{array}$ & 6.94 & 5.8358 & 12.42 & 6.181 & 0.000142 \\
\hline
\end{tabular}

The above table shows that level of Depression (GDI) seems slight high among the respondents of old age home. Old age home respondents are very prone to depression. Level of depression shows low among the respondents of family. The 
t Test result shows significance. So, the hypothesis of H-I is true.

Table 3

Showing Mean, SD \& T Scores about depression (Geriatric Depression Inventory-GDI) among the Respondents (elderly persons) of Family and Old age Home:

\begin{tabular}{|c|c|c|c|c|c|}
\hline $\mathrm{N}=50$ & \multicolumn{2}{|c|}{$\begin{array}{c}\text { Respondents } \\
\text { of Family }\end{array}$} & \multicolumn{2}{c|}{$\begin{array}{c}\text { Respondents } \\
\text { of Old age Home }\end{array}$} & \\
\hline & Mean & SD & Mean & SD & t-Test \\
\hline GDI (Female) & 7.04 & 6.00 & 12.64 & 6.58 & 0.0014 \\
\hline GDI (Male) & 6.84 & 5.785 & 12.2 & 5.894 & 0.0010 \\
\hline GDI (Male-Female) & 6.84 & 5.785 & 12.64 & 6.569 & 0.0008 \\
\hline GDI (Female-Male) & 7.04 & 6.003 & 12.2 & 5.894 & 0.0017 \\
\hline
\end{tabular}

The above table shows that level of depression (GDI) among the total respondents and male \& female respondents of Family and Old age home. The all $\mathrm{t}$ Test result shows significance as results are <.001-.005. There are significant differences of level of depression shows among the two groups of total respondents as well as female groups and male groups and also among the male female and vice versa. So the hypothesis of $\mathrm{H}-\mathrm{II}$ is true.

\section{Conclusion}

The study reveals that depression is higher among the persons living in Old age Homes. The female respondents are more prone to depression rather than male.

Finally it also has been reveals that several changes going on in our society and globalization play as change catalyst to develop quite a lot of institutions and old age homes but the residents of old age homes are not happy with their living.

\section{References}

[1] Birren E. James, Encyclopedia of Gerontology, (1996) Vol. I \& II - Age, Ageing, and the Aged, Vol-1, P-365, 505 .

[2] Bhattacharya Swaha \& Mukherjee Monimala, Perception of the elderly (2008), Global Visson Publishing House, New Delhi.

[3] Howard S. Friedman, (1998), Encyclopedia of Mental Health, Vol.-1, P-27, 535, 681.

[4] Papalia Dinae E A and Olds Sally Wendkas (1992), 'Human Development' Fifth Edition, Tata Mc Graw Hill, New Delhi

[5] Ram Chandra Srivastava, 'The Problems of the Oldage' Classical Publishing Company, New Delhi

[6] Potts, MK. Social Support and Depression among Older Adults Living Alone: The Importance of Friends Within and Outside of a Retirement Community. Social Work.1997; 42: 348-362. [PubMed]

[7] Hamarat, Errol; Thompson, Dennis; Steele, Don; Matheny, Ken et al. (2002) Age differences in coping resources and satisfaction with life among middle-aged, young-old and oldest-old adults. Journal of Genetic Psychology, vol.163 (3), 360-367.

[8] Haines, Valerie A. and Henderson, Linda, J. (2002). Targeting social support: A network assessment of the convoy model of social support. Canadian Journal of Ageing, vol.21 (2), 243-256.

[9] Lawton, M. Powell, Mass, Miriam S; Winter, Laraine \& Hoffman, Christine. (2002). Motivation in Later Life: Personal Projects \& Well-being. Psychology \& Ageing, vol.17 (4), 539-547.

[10]Lee, Christian \& Russell, Anne, (2003). Effects of Physical Activity on Emotional Well-being among Older Australian Women: Cross-Sectional \& Longitudinal Analysis. Journal of Psychosomatic Research, vol.54 (2), 155-160.

[11] Sullivan, Mark D. (2003). Hope and Hopelessness at the end of life. American Journal of Geriatric Psychiatry, vol.11 (4), 393-405. 